\title{
Metronidazole removal by means of a combined system coupling an electro-Fenton process and a conventional biological treatment: by- products monitoring and performance enhancement
}

\author{
Arwa ABOUDALLE ${ }^{a, b}$, Hayet DJELAL ${ }^{a, d}$, Florence FOURCADE $^{a}$, Lionel Domergue ${ }^{a}$, \\ Aymen Amin ASSADI ${ }^{a}$, Thomas LENDORMI ${ }^{\mathrm{e}}$, Samir TAHA ${ }^{\mathrm{b}, \mathrm{c}}$, Abdeltif AMRANE ${ }^{\mathrm{a}}$ \\ a. Univ rennes, Ecole Nationale Supérieure de Chimie de Rennes, CNRS, ISCR - UMR6226, F-35000 \\ Rennes, France \\ b. Laboratoire de Biotechnologies Appliquées, Centre AZM pour la recherche en biotechnologies et ses \\ applications, Ecole doctorale des sciences et technologies, Université Libanaise, Rue Al-Mitein, Tripoli, \\ Liban. \\ c. Faculté de santé publique, Université Libanaise, quartier Dam et Farz, Tripoli, Liban. \\ d. Ecole des Métiers de l'Environnement, Campus de Ker Lann, 35170 Bruz, France \\ e. Université Bretagne Sud, FRE CNRS 3744, IRDL, F-56300 Pontivy, France
}

Graphical abstract

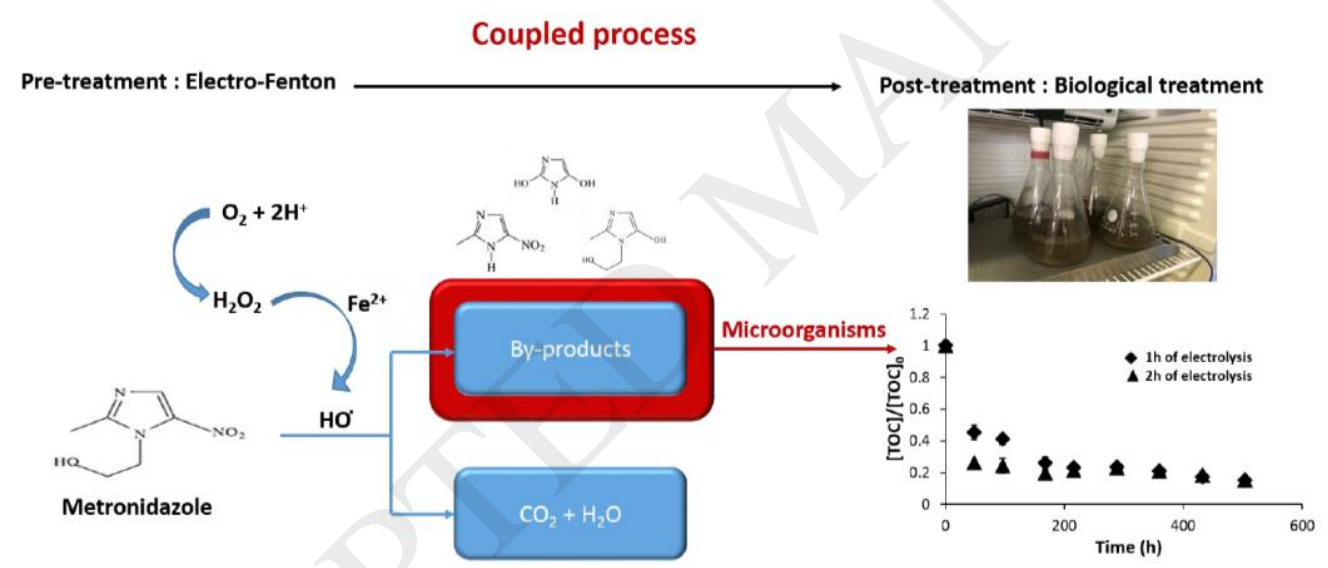

Highlights :

- Biological treatment of MTZ led to $22 \%$ of degradation after 21 days of treatment

- The application of EF led to total MTZ degradation with low level of mineralization

- The biodegradability increased from 0 to 0.46 for the BOD5 on COD ratio

- By-products were identified by UPLC-MS/MS and a degradation pathway was proposed.

- Overall removal yield of the MTZ effluent during the combined process was $87.4 \%$ 


\begin{abstract}
In order to mineralize Metronidazole (MTZ), a process coupling an electro-Fenton pretreatment and a biological degradation was implemented. A mono-compartment batch reactor containing a carbon-felt cathode and a platinum anode was employed to carry out the electro-Fenton pretreatment of MTZ. A total degradation of MTZ (100 mg.L $\left.\mathrm{L}^{-1}\right)$ was observed at $0.07 \mathrm{~mA} . \mathrm{cm}^{-2}$ after only $20 \mathrm{~min}$ of electrolysis. Yet, after 1 and 2 hours of electrolysis, the mineralization level remained low (16.2\% and $32 \%$ respectively), guaranteeing a significant residual organic content for further biological treatment. LC-MS/MS was used to determine the intermediates by-products and hence to propose a plausible degradation pathway. An increase from 0 to 0.44 and 0.6 for 1 and 2 hours of electrolysis was observed for the $\mathrm{BOD}_{5} / \mathrm{COD}$ ratio. Thus, from 1 hour of electro-Fenton pretreatment, the electrolysis byproducts were considered biodegradable. A biological treatment of the electrolysis by-products after 1 and $2 \mathrm{~h}$ was then realized. The mineralization yields reached very close values, about $84 \%$ for 1 and 2 h of electrolysis after 504 hours of biological treatment, namely close to $89 \%$ for the overall process, showing the pertinence of the proposed coupled process.
\end{abstract}

\title{
Keywords : Biological treatment; activated sludge; Electro-Fenton process; Metronidazole; by-products monitoring
}

\section{Introduction}

Because of high levels of consumption, long persistence in the environment and a very varied composition, antibiotics are considered as very critical water pollutants. They are clearly detected in sewage water even after treatment because of their recalcitrance [1]. The pollution generated by pharmaceutical drugs are originated from pharmaceutical industries emission, domestic wastes and hospital effluents [2-4]. Indeed, from the French ministry of the Ecology and from the Sustainable-development division of the Ecology ministry [5], one of the three major sources of water pollution is known to be industrial discharge and its relative part is respectively $15 \%$.

To eliminate the pharmaceutical drugs from water, some processes such as adsorption on activated carbon in aqueous phase [6-8] are studied. This class of processes, although efficient, relies on a transfer of pollution from the aqueous phase to the solid phase and concerns low 
concentrated effluents. Among the destructive methods, biological treatment has been also tested, but appears not really efficient for such biorecalcitrant compounds and requires a long time for its completion $[9,10]$. Advanced oxidation processes AOP, based on a non-selective generation of powerful actives species such as ${ }^{\circ} \mathrm{OH}$, have shown their efficiency for the degradation of several organic molecules [1] and for concentrated effluents. However, their employment for a complete mineralization is generally pricey and requires additional energy and consumption reagents [11].

For concentrated effluents, to combine the advantages of both kind of processes, their coupling have been proposed, namely the use of AOP as pre-treatment or post-treatment and biological treatment. The order of the coupling of the processes depends on the effluent load in nonbiodegradable compound [11]. If the effluent contains a large amount of biodegradable compounds with low concentrations of recalcitrant compounds, a biological treatment is applied in pretreatment in order to remove all the biodegradable part of the effluent and subsequently the AOP is applied to remove the refractory part [12]. However, if the effluent contains toxic molecules for microorganisms and / or have biodegradability below 0.4 , the AOP will take the place upstream. In this case, the aim of the AOP is to improve the biodegradability of the organic pollutant or to reduce its toxicity, thus enabling relatively inexpensive subsequent biological treatment [11-14]. Oller et al, reported in their review the interest and the efficiency of a combined process AOP-Biological treatment to treat such type of effluent, containing recalcitrant contaminants [11]. Among AOP, Electrochemical Advanced Oxidation Processes (EAOPs) are considered as ones of the most commonly used AOP during coupled processes, since they are characterized by several advantages, such as high efficiency, moderate operating costs, facility of automation and compatibility with environmental applications $[15,16]$. Ganzenko et al, confirmed the effectiveness of the coupling processs (EAOP and biological treatment) compared to the individual treatment [12].

Being among the most efficient EAOPs, Electro-Fenton (EF) process is applied as a pretreatment in the present study followed by a conventional biological treatment. The EF process is considered as an environmentally clean treatment [17]. It allows to minimize the use of the reagent and the formation of ferric hydroxides. This process is based on the in-situ generation of $\mathrm{H}_{2} \mathrm{O}_{2}$ by reducing the dissolved oxygen (Eq. (1)). The generated $\mathrm{H}_{2} \mathrm{O}_{2}$ reacts with the dissolved Fe (II) to produce powerful radicals ${ }^{\circ} \mathrm{OH}$ and $\mathrm{Fe}$ (III) (Eq. (2)). Fe(II) was regenerated by the cathodic reduction of Fe(III) (Eq. (3)) [18]. According to Olvera-Vargas et al, this type of coupling is called bio-electro-Fenton (Bio-EF), which combines the high oxidation power 
of $\mathrm{EF}$ and the profitability of biological treatment for the removal of refractory compounds [16].

$$
\begin{array}{lr}
\mathrm{O}_{2}+2 \mathrm{H}^{+}+2 \mathrm{e}^{-} \rightarrow \mathrm{H}_{2} \mathrm{O}_{2} & E^{\circ}=0.69 \mathrm{~V} / \mathrm{SHE} \\
\mathrm{H}_{2} \mathrm{O}_{2}+\mathrm{Fe}^{2+} \rightarrow \mathrm{Fe}^{3+}+\mathrm{OH}^{-}+{ }^{\circ} \mathrm{OH} & \text { (Fenton's reaction) } \\
\mathrm{Fe}^{3+}+\mathrm{e}^{-} \rightarrow \mathrm{Fe}^{2+} & E^{\circ}=0.77 \mathrm{~V} / \mathrm{SHE}
\end{array}
$$

This study focuses therefore on the application of a coupled process (electro-Fenton/ biological treatment) to treat an effluent loaded with a recalcitrant pharmaceutical drug, Metronidazole (MTZ). This antibacterial and anti-inflammatory antibiotic is detected in treated sewage water [19] and is characterized by its non-biodegradability, its high solubility in water, its toxicity to aquatic system, its potential mutagenicity, and its carcinogenicity [20-22]. The adsorption of metronidazole on granular activated carbon followed a Langmuir model with a maximal sorption capacity of $110.64 \mathrm{mg} \cdot \mathrm{g}^{-1}$ [23] but for a total MTZ removal, a post treatment was necessary. Degradation processes such as photocatalytic ozonation [24], sono-Fenton [25], anodic oxidation [26], direct photolyse, Fenton and photo-Fenton [27] were tested with degradation yields up to $85 \%$.

Métronidazole removal was also studied by photo-electro-Fenton and mineralization yield reached $53 \%$ [28].

In a previous paper on the mineralization of metronidazole, the objective was to optimize the electro-Fenton process and to verify the feasibility of coupling electro-Fenton with a biological treatment [29]. This study aims to improve the mineralization rate of the MTZ by applying a process coupling electro-Fenton and biological treatment. In this sense, a follow-up of the mineralization of the MTZ, the biodegradability of the by-products of electrolysis and the identification of by-products during the electro-Fenton process and the biological treatment were examined to understand the degradation mechanism of MTZ 


\section{Materials and methods}

\subsection{Chemicals and materials}

The target pollutant, metronidazole, MTZ, (2-methyl-5-nitroimidazole-1-ethanol), and the byproduct of MTZ, MAA (2-methyl-5-nitroimidazole-1-acetic acid), were obtained from SigmaAldrich. $\mathrm{FeSO}_{4} \cdot 7 \mathrm{H}_{2} \mathrm{O}$ (purity $99 \%$ ) and $\mathrm{Na}_{2} \mathrm{SO}_{4}$ (purity $99 \%$ ) were purchased from Acros Organics (Thermo Fisher Scientific, Geel, Belgium). Ultrapure water (Millipore Elga) was used to prepare all solutions.

\subsection{Electrochemical Apparatus and Procedures}

An electrochemical batch reactor containing $250 \mathrm{~mL}$ of solutions was employed in all experiments carried out at ambient temperature $\left(20^{\circ} \mathrm{C}\right)$. An ammeter power supply (Microsonic systems, Microlab MX 20V-2A, France) was used to apply the current intensity at $0.07 \mathrm{~mA} . \mathrm{cm}^{-}$ 2 . A tri-dimensional piece of graphite felt of $42 \mathrm{~cm}^{3}$ (geometrical volume) (Le Carbone Lorraine RVG 4000 Mersen, Paris la Défense, France) was the working electrode (cathode) positioned on the inner wall of the cell; while cylindrical platinum $\left(32 \mathrm{~cm}^{2}\right)$ was used and placed at the center of the electrochemical reactor as an anode. The latter was surrounded by the cathode to get a good potential distribution. $10 \mathrm{~min}$ prior the electrolysis and throughout the experiments, compressed air was bubbled into the solution $\left(0.5 \mathrm{~L}_{\mathrm{min}} \mathrm{min}^{-1}\right)$ in order to reach a stationary $\mathrm{O}_{2}$ concentration. Just before the start of the electrolysis, a catalytic quantity of $\mathrm{FeSO}_{4} \cdot 7 \mathrm{H}_{2} \mathrm{O}$ was added into the cell $\left(0.1 \mathrm{mmol} . \mathrm{L}^{-1}\right)$. The ionic strength was maintained constant by the addition of $50 \mathrm{mmol} . \mathrm{L}^{-1} \mathrm{Na}_{2} \mathrm{SO}_{4}$.

\subsection{Preparation of activated sludge}

Activated Sludge used in this study was collected from the municipal wastewater treatment plant (Rennes Beaurade, France). The activated sludge was maintained in an $8 \mathrm{~L}$ reactor in the laboratory. For growth and conservation, the activated sludge was cultivated under oxygen flow on the following mineral medium $\left(\mathrm{g} . \mathrm{L}^{-1}\right)$ : peptone, $0.64 ; \mathrm{K}_{2} \mathrm{HPO}_{4}, 0.11 ; \mathrm{NH}_{4} \mathrm{Cl}, 15.2$; $\mathrm{CH}_{3} \mathrm{COONa}, 140$; and some drops per month of Viandox as a supplementary source of carbone. Prior to the inoculation, in order to avoid any residual carbon and mineral source other than those contained in the culture media, the active sludge was washed three times with tap water and two times with ultra-pure water. 


\subsection{Determination of the biological oxygen demand $\left(\mathrm{BOD}_{5}\right)$}

$\mathrm{BOD}_{5}$ measurements were carried out in Oxitop IS6 (from WTW, Alès, France) at $20^{\circ} \mathrm{C}, \mathrm{pH} 7$ and in obscurity during 5 days in order to evaluate the biodegradability of MTZ molecule and its by-products. For inoculation, an initial microbial concentration of 0.05 g.L $\mathrm{L}^{-1}$ was needed. The mineral basis, nitrification inhibitor, and buffer solution presented in the table 1 were used for all experiments.

A control sample containing biodegradable compounds, namely glutamic acid (150 mg. $\mathrm{L}^{-1}$ ) and glucose $\left(150 \mathrm{mg} . \mathrm{L}^{-1}\right)$ was carried out to check the viability of the activated sludge. A blank solution, containing water (without a source of carbon) was performed to deduce the biological oxygen demand corresponding to the endogenous respiration.

\subsection{Biological treatment}

Cultures were performed in duplicate for 21 days at $25^{\circ} \mathrm{C}$ and in $500 \mathrm{~mL}$ Erlenmeyer flasks, magnetically stirred (200 rpm), closed with a cellulose cap to guarantee oxygenation and loaded with $200 \mathrm{~mL}$ of non-treated Metronidazole or Metronidazole solutions electrolyzed by EF for 1 or 2 hours. An initial activated sludge concentration of $0.5 \mathrm{~g} \mathrm{~L}^{-1}$ was inoculated and the following minerals were used for all experiments (mg.L $\left.{ }^{-1}\right): \mathrm{K}_{2} \mathrm{HPO}_{4}, 208 ; \mathrm{KH}_{2} \mathrm{PO}_{4}, 85$; $\mathrm{Na}_{2} \mathrm{HPO}_{4} .2 \mathrm{H}_{2} \mathrm{O}, 154.4 ; \mathrm{MgSO}_{4} .7 \mathrm{H}_{2} \mathrm{O}, 22.6 ; \mathrm{CaCl}_{2}, 27.6 ; \mathrm{FeCl}_{3} .6 \mathrm{H}_{2} \mathrm{O}, 0.26 ; \mathrm{NH}_{4} \mathrm{Cl}, 75$. [30]. The $\mathrm{pH}$ was then fixed to 7.0 with $\mathrm{NaOH}$ solution $\left(2 \mathrm{mmol} . \mathrm{L}^{-1}\right)$. Samples were taken regularly for TOC and HPLC measurements and filtered on $0.45 \mu \mathrm{m}$ Chromafil® Xtra PET $-45 / 25$.

\subsection{Biosorption tests}

A protocol similar to that of the biological treatment was used, except that culture medium was inoculated with two types of inocula: activated sludge and sludge inactivated by autoclaving at $120^{\circ} \mathrm{C}$ for $20 \mathrm{~min}$ in order to avoid the phenomenon of biodegradation and evaluate only the biosorption. Metronidazole and its electrolysis by-products were inoculated with the two types of biomass (active and inactive) at a concentration of 0.5 g. $\mathrm{L}^{-1}$ in the presence of the minerals used in the biological treatment at $25^{\circ} \mathrm{C}$ with a stirring of $200 \mathrm{rpm}$; regular samples were taken during $180 \mathrm{~min}$. The samples taken were then analyzed by TOC-meter. Experiments were performed in $500 \mathrm{~mL}$ Erlenmeyer flasks. 


\subsection{Phytotoxicity test}

The phytotoxicity test was carried out using seeds of garden cress (Lepidium Sativum). A nontoxic compound must have a germination index (GI) greater than $80 \%$. For its determination, the preparation of 10 Petri dishes containing filter paper, moisten with $5 \mathrm{ml}$ of MTZ or MAA was carried out. Then, the deposition of 10 seeds of garden cress on the filter paper was realized. The petri dishes were stored in the dark at $25^{\circ} \mathrm{C}$ for 48 hours. The same steps must be carried out for the control, with Petri dishes containing only tap water.

$\%$ Germination Index $=\%$ Germination $\mathrm{x} \%$ Root growth

$\%$ germination $=\frac{\text { Number of germinated seeds for the test }}{\text { Number of germinated seed for control }} \times 100$

$\%$ Root Growth $=\frac{\text { Size of roots of germinated seeds for test }}{\text { Size of roots of germinated seeds for control }} \times 100$

\subsection{Analytical procedures}

\subsubsection{LC-MS/MS method}

The identification of the different by-products from electrolysis as well as from the biological treatment was determined by Liquid Chromatography coupled to Mass Spectrometry (UPLCMS/MS). The analytes was separated by a Waters Acquity UPLC system (Waters, Manchester, UK). The system consisted of an Acquity UPLC binary solvent manager, an Acquity UPLC sample manager and an Acquity UPLC column heater equipped with a Waters Acquity UPLC BEH C-18 column $(2.1 \mathrm{~mm} \times 100 \mathrm{~mm} ; 1.7 \mu \mathrm{m})$ (Milford, MA, USA). Two mobile phases A and B were used to carry out the UPLC elution gradient. The first phase was performed in ultrapure water with $0.1 \%$ formic acid; the second was performed in acetonitrile with $0.1 \%$ formic acid. In order to separate the analytes on the column, the process was carried out with a gradient of phase $\mathrm{A} /$ phase $\mathrm{B}$ at the flow rate of $0.4 \mathrm{~mL} \cdot \mathrm{min}^{-1}$. The starting eluent composition consisted of $0 \% \mathrm{~A} / 100 \% \mathrm{~B}$ for $1 \mathrm{~min}$; then the proportion of solvent increased linearly to reach $100 \%$ in 8 min.

Waters Micromass Quattro Premier (Waters Corporation, Manchester, UK) triple quadrupole mass spectrometer was used to detect the separated compounds. The mass spectrometer was constituted of an electrospray source in positive ionization mode with a cone potential of $30 \mathrm{~V}$. The ionization source conditions were: capillary voltage of $3.0 \mathrm{kV}$ and source temperature of 
$350^{\circ} \mathrm{C}$. The cone and desolvation gas flows were $50 \mathrm{~L} \cdot \mathrm{h}^{-1}$ and $750 \mathrm{~L} \cdot \mathrm{h}^{-1}$ respectively. These values were obtained from a nitrogen source, the Peak Scientific NM30LA (Peak Scientific, Inchinann, United Kingdom). High-purity argon (99.99 \%, Air Liquid, Paris, France) was used as collision gas and was regulated at $0.1 \mathrm{~mL} \mathrm{~min}^{-1}$. Collision energy of $25 \mathrm{eV}$ was fixed during the implementation of analyses in full scan and daughter scan modes. Spectra were acquired between 80 and $500 \mathrm{mz}^{-1}$ and the data were treated with Micromass Mass-Lynx 4.1 software.

\subsubsection{Ionic chromatography (CI)}

DIONEX DX120 ion chromatography was used to identify the generated carboxylic acids and to quantify nitrite and nitrate ions. The chromatograph was equipped with a conductivity detector, using an anion exchange column AS19 (4 x $250 \mathrm{~mm})$ as the stationary phase, and a solution of $\mathrm{KOH}\left(12 \mathrm{~mol} . \mathrm{L}^{-1}\right)$ in water as the mobile phase. A gradient elution mode was used to perform all analyses. It started with $10 \mathrm{mmol} . \mathrm{L}^{-1}$ of $\mathrm{KOH}$ during $10 \mathrm{~min}$ then increased linearly to $45 \mathrm{mmol} . \mathrm{L}^{-1}$ from 10 to $25 \mathrm{~min}$ and finally kept at $45 \mathrm{mmol} . \mathrm{L}^{-1}$ of $\mathrm{KOH}$ from 25 to $35 \mathrm{~min}$. The flow rate was set at $1 \mathrm{~mL} \mathrm{~min}^{-1}$.

\subsubsection{High performance liquid chromatography (HPLC)}

The evolution of MTZ concentrations was monitored by HPLC using Waters 996 system equipped with Waters 996 PDA (Photodiode Array Detector) and Waters 600LCD Pump. Waters C-18, (4.6 x $250 \mathrm{~mm} \times 5 \mu \mathrm{m})$ reversed-phase column was used to achieve the separation. A mixture of acetonitrile/ ultra-pure water (20/80, v/v) with $0.1 \%$ formic acid was used as eluent and the flow rate was $1 \mathrm{~mL} \cdot \mathrm{min}^{-1}$. The detection of Metronidazole was carried out at $318 \mathrm{~nm}$ and the retention time was $4.3 \mathrm{~min}$.

\subsubsection{Total organic carbon (TOC) and total nitrogen (TN) measurements}

TOC and TN were measured by means of a TOC- $\mathrm{V}_{\mathrm{CPH} / \mathrm{CPG}}$ Total Organic Analyzer Schimadzu. Organic Carbon compounds were combusted and converted to $\mathrm{CO}_{2}$ which was detected by a non-dispersive Infra-Red Detector (NDIR). Dissolved Nitrogen compounds were combusted and converted to NO which was then mixed with Ozone chemiluminescence for detection by a photomultiplier [17]. The mineralization current efficiency (MCE) was calculated from 


\subsubsection{Ammonium species quantification}

The monitoring of ammonium species $\left(\mathrm{NH}_{4}^{+}\right)$was realized via the spectrophotometric Nessler method at $420 \mathrm{~nm}[31]$.

\subsubsection{Chemical Oxygen Demand (COD) measurements}

COD was measured by Nanocolor® CSB 160 kits from Macherey-Nagel (Düren, Germany) by a Nanocolor photometer. The oxidation is carried out by potassium dichromate $\left(\mathrm{K}_{2} \mathrm{Cr}_{2} \mathrm{O}_{7}\right)$ in a strong acid medium $\left(\mathrm{H}_{2} \mathrm{SO}_{4}\right)$ and at a temperature of $160{ }^{\circ} \mathrm{C}$ for 30 minutes.

\section{Results and discussion}

\subsection{Pretreatment of MTZ by the electro-Fenton process.}

The effects of the electro-Fenton process on Metronidazole removal and mineralization are displayed in Fig 1. The electrolysis was carried out at $0.07 \mathrm{~mA} . \mathrm{cm}^{-2}$ with $0.1 \mathrm{mmol} . \mathrm{L}^{-1}$ of Fe (II) and 0.05 mol.L $\mathrm{L}^{-1}$ of $\mathrm{Na}_{2} \mathrm{SO}_{4}$ with and initial amount of MTZ of $100 \mathrm{mg} . \mathrm{L}^{-1}$. These conditions were previously determined to be optimal in a previous study [29]. After 20 min of electrolysis, a total degradation of MTZ was observed with an apparent kinetic (kapp) of 0.24 $\min ^{-1}$; while mineralization remained limited to $32 \%$ after $120 \mathrm{~min}$ with a mineralization current efficiency (MCE) [18] of $26.3 \%$. This value was calculated from the following equation: $\mathrm{C}_{6} \mathrm{H}_{9} \mathrm{~N}_{3} \mathrm{O}_{3}+18 \mathrm{H}_{2} \mathrm{O} \rightarrow 6 \mathrm{CO}_{2}+3 \mathrm{NO}_{3}{ }^{-}+45 \mathrm{H}^{+}+42 \mathrm{e}^{-}$. This low mineralization rate is related to the formation of ${ }^{\circ} \mathrm{OH}$ which may be insufficient to completely mineralize MTZ. The recalcitrance of MTZ for mineralization was previously observed during electro-Fenton process [28], using nano-scale zero-valent iron [32] and electro-Fenton with a $\mathrm{Ce} / \mathrm{SnO}_{2}-\mathrm{Sb}$ coated titanium anode [33] 


\subsection{Identification of the intermediates products}

Table 2 summarizes the various compounds detected via LC-MS/MS during the electro-Fenton treatment (from T0 min to T120 min) of $100 \mathrm{mg} . \mathrm{L}^{-1}$ of metronidazole at $0.07 \mathrm{~mA} . \mathrm{cm}^{-2}$. These results showed that the removal of metronidazole is complex leading to various heterocyclic intermediates.

Based on the identification shown in the Table 2, a pathway for the degradation of metronidazole by hydroxyl radicals can be suggested (Fig.2). Hydroxyl radicals can attack metronidazole by different ways (Fig. 2): N-denitration leading to the release of a nitrate group, oxidation of $\mathrm{N}$-ethanol to $\mathrm{N}$-acetic acid, split of the $\mathrm{N}$-ethanol group and hydroxylation that consists of one $\mathrm{OH}$ group substitution. The detection of the by-products of MTZ degradation via radical attack have been reported in various studies [28,34-37]. In the study of Cheng et al., the molecules 2 and 3 were detected using nanoscale zero-valent iron particles to remove the metronidazole [36], it can also be noted that the molecules 1,4, 5 and 7 were detected in the study of Pérez et al. on the degradation of metronidazole by solar photoelectro-Fenton [28].

It can be suggested that the degradation was initiated by the formation of compound 1 after the oxidation of the $\mathrm{N}$-ethanol group or by the formation of compound 2 after an $\mathrm{N}$-denitration of MTZ. Compound 2 can produce compound 5 after hydroxylation and compound 6 after oxidation of the lateral N-ethanol group. Compound 4 can be obtained by hydroxylation of compound 1 or oxidation of the lateral $\mathrm{N}$-ethanol group of compound 5. Hydroxyl radical attack may cause the split of the $\mathrm{N}$-acetic acid group which produced in our case compounds 7, 9 and 10. Substitution of the $\mathrm{OH}$ group on the imidazole ring facilitated the opening of the ring and produced small aliphatic carboxylic acids such as formic acid and oxalic acid. These acids were detected using ion chromatography (Table 2) and highlighted the mineralization of the target compound.

\subsection{Evolution of the generated inorganic ions}

MTZ contains two nitrogen atoms in its ring and a substituted nitrite group on the ring. Fig.3 illustrates time-courses of the quantification of nitrate and nitrite assayed by ion chromatography, ammonium by the Nessler method and total nitrogen by TOC-meter during electrolysis. There was no formation of nitrite; while nitrate formation was detected since 60 min of electrolysis, that resulted most likely from $\mathrm{N}$-denitration, with a liberation of a nitrate group to obtain, for example, compounds 4, 5, 6, 9 detected by LC-MS/MS (Table 2). After 2 
hours of electrolysis, its concentration reached $0.3 \mathrm{mmol} . \mathrm{L}^{-1}$. It is also observed that the generation of ammonium ions began after $60 \mathrm{~min}$ of electrolysis; they resulted from the radical attack of the nitrogen atoms contained in the metronidazole cycle. The ammonium concentration reached $0.45 \mathrm{mmol} . \mathrm{L}^{-1}$ at the end of the electrolysis. $38.7 \%$ of the nitrogen atoms of the target molecule were transformed into ammonium, while $28.0 \%$ were transformed into nitrates after 120 min of electrolysis. The percentage of undetected nitrogen may be related to the presence of nitrogen by-products in solution (Table 2). However, the total nitrogen concentration was constant throughout the treatment, which shows the absence of nitrogen evolution $\left(\mathrm{N}_{2}\right)$. Similar results were obtained by Annabi et al. on the production of nitrogen ions during electro-Fenton treatment of Enoxacin. Indeed, no nitrite $\mathrm{NO}_{2}{ }^{-}$anions were detected; $24 \%$ and $5 \%$ of the nitrogen atoms were transformed into ammonium and into nitrates after 120 min of electrolysis respectively and the total nitrogen concentration was constant [17].

\subsection{MTZ biodegradability study.}

The $\mathrm{BOD}_{5}$ on $\mathrm{COD}$ ratio assesses the biodegradability of a solution. The solution is considered as biodegradable if the ratio is greater than or equal to 0.4 [38]. The objective of this estimation is to determine the feasibility of a biological treatment for MTZ mineralization subsequently to the electro-Fenton pretreatment.

Fig.4 displays the biodegradability in terms of time of electrolysis for MTZ under the optimal conditions of the electro-Fenton process. The non-biodegradability of the MTZ before electrolysis can be noted. After 30 min of electrolysis, a total degradation of MTZ was reached (Fig.1); while the solution remained poorly biodegradable with a ratio of $0.24(<0.4)$. The first by-products of electrolysis were therefore relatively resistant to microorganisms since their chemical structures are very close to the target molecule. However, after 60 min electrolysis the solution became biodegradable, 0.46, namely above the threshold level (0.4). It can be inferred that after $60 \mathrm{~min}$, an important part of the recalcitrant by-products have been oxidized. An increase of biodegradability was observed after 120 min of electrolysis, with a $\mathrm{BOD}_{5}$ on COD ratio of 0.7. The choice of electrolysis duration can be posed for the EF-Bio coupling. Indeed, 60 min electrolysis was more economic from an energetic point of view, while 120 min electrolysis provided a higher level of biodegradability. 


\subsection{Biosorption tests for MTZ and its by-products}

Biosorption is defined as the adsorption of organic molecules on the wall of microorganisms. This accumulation is caused by a complex mechanism [39]. It is considered as a fast phenomenon, which occurs within the first few hours.

In order to evaluate biosorption phenomenon, it is possible to use activated sludge according to some authors $[19,40,41]$. Using living microorganisms, two phenomena can occur: biosorption or / and biodegradation. In order to avoid possible biodegradation even if a short experimental time was considered, inactivated sludge was used to determine the biosorption of MTZ and the electrolyzed by-products (Fig.5). The adsorption capacity of inactive microorganisms is higher than that of active microorganisms [42], due to the increase of the adsorption surface. Since the TOC value of the inactive microorganisms was stable (Fig.5), there was no biosorption of MTZ and its by-products on inactivated sludge. It can be then supposed that this phenomenon can be considered as negligible with activated sludge. It was confirmed for MTZ, since constant TOC values were also observed (Fig.5); while a slight decrease was observed for the biosorption of the by-products on activated sludge. This may be related to the biodegradation of the highly biodegradable compounds obtained after the electroFenton pretreatment, as confirmed thereafter.

\subsection{Biological treatment of $M T Z$}

A biological treatment was carried out first with non-treated MTZ as a sole source of carbon. Fig.6 shows that TOC values remained nearly constant during 504 hours of culture; the lack of mineralization was expected and in agreement with the low value obtained for the $\mathrm{BOD}_{5}$ on COD ratio. However, the concentration of metronidazole decreased slightly. In fact, it can be assumed that at the beginning of culture, microorganisms were not able to assimilate the metronidazole, a clear decrease of $22 \%$ was only observed from $216 \mathrm{~h}$ of culture; this decrease was also detected by Saidi et al [19], who observed a degradation of $15 \%$ after 10 days of MTZ treatment by activated sludge.

Fig. 7 shows that the decrease in MTZ concentration was accompanied by the progressive production of a by-product. LC-MS/MS analyzes allowed to identify it as 2-methyl-5- 
nitroimidazole-1-acetic acid (MAA), which was also detected during the electro-Fenton pretreatment (Table 2). It was also detected as a by-product of MTZ by solar photo-electroFenton treatment [28], by photo-Fenton treatment [35]. Furthermore, MAA was detected as one of the MTZ metabolites formed by the action of the cytochrome P-450 system present in the liver [43]. The MAA activity against anaerobes is negligible compared to MTZ activity [44]; while it was shown in the present study that the phytotoxicity of MAA is higher than MTZ with a percentage of germination index of 65 and 74 respectively (Fig. 8 ). The constant concentration of total organic carbon (Fig. 6) and the formation of MAA (Fig. 7) indicated that MTZ had not undergone mineralization (Conversion to $\mathrm{CO}_{2}$ and $\mathrm{H}_{2} \mathrm{O}$ ) but biotransformation (transformation of compound by the enzymatic activity of microorganisms to form another compound) and that microorganisms did not use MAA as a source of carbon or energy. At the end of the activated sludge treatment at $504 \mathrm{~h}$, the TOC amount corresponded to $78 \%$ of untreated MTZ and $22 \%$ of produced MAA. These compounds were accumulated in the medium without being able to be eliminated, confirming the limits of the biological treatment with activated sludge and the need for a pretreatment.

\subsection{Biological treatment of MTZ by-products}

In order to confirm the efficiency of the coupled process, electro-Fenton and biological treatment, an activated sludge culture of by-product solutions after 1 or $2 \mathrm{~h}$ of electrolysis was carried out. The TOC was checked for $504 \mathrm{~h}$ and its monitoring for the pretreated solutions is shown in Fig. 9. Unlike pure MTZ, mineralization yields were clearly improved during the biological treatment of electrolyzed solutions, highlighting the pertinence of an electro-Fenton pretreatment of MTZ prior to a biological process.

Indeed, mineralization yield after $168 \mathrm{~h}$ increased to 74 and $80 \%$ for the solutions pretreated during of $1 \mathrm{~h}$ and $2 \mathrm{~h}$, respectively. The TOC evolution showed that the major part of the byproducts from electrolysis was easily biodegradable. During the first $120 \mathrm{~h}$ of biological pretreatment, it can be observed that the mineralization of the pretreated solution for $2 \mathrm{~h}$ was higher than for $1 \mathrm{~h}$ of pretreatment; it was in agreement with the biodegradability results (Fig. 4). Nevertheless, no significant increase was detected from $168 \mathrm{~h}$ to $288 \mathrm{~h}$, which corresponded most likely to an acclimation period of the microorganisms to the most refractory MTZ byproducts. Then, from $288 \mathrm{~h}$ to the end of the culture, the TOC value decreased slightly to reach $84.6 \%$ and $83.3 \%$ for $1 \mathrm{~h}$ and $2 \mathrm{~h}$ respectively. Such behavior of microorganisms toward electrolyzed solutions, namely a rapid assimilation of the biodegradable part followed by an 
acclimation period and then an assimilation of a part of the remaining refractory compounds, was in agreement with other findings $[38,40]$.

It should be observed that even if similar final mineralization yields (after $504 \mathrm{~h}$ ) were obtained, higher mineralization yields were observed during the first 7 days in the case of $2 \mathrm{~h}$ electrolysis, in agreement with the higher biodegradability value, 0.46 and 0.7 for 1 and $2 \mathrm{~h}$ respectively (Fig.4). However, after 504 h, similar mineralization yields were obtained for 1 and $2 \mathrm{~h}$ of pretreatment.

Indeed, an additional pretreatment time of $1 \mathrm{~h}(2 \mathrm{~h}$ in total $)$ did not affect the refractory product which remained after a $1 \mathrm{~h}$ pretreatment. The gain in terms of mineralization during biological treatment was not enhanced by the supplementary $1 \mathrm{~h}$ of electrolysis. It can be deduced from this result that the application of $1 \mathrm{~h}$ of electrolysis is more cost-effective and provides a similar percentage of mineralization. Similar result was obtained in the study of Ferrag-Siagh et al, with close mineralization yield values obtained after biological treatment of tetracycline for 2 and $4 \mathrm{~h}$ of electro-Fenton pretreatment despite a higher biodegradability after $4 \mathrm{~h} \mathrm{[40].}$

\subsection{By-products monitoring during the biological treatment}

After determining the appropriate electro-Fenton pretreatment time, LC-MS/MS analyzes were carried out to detect the electrolysis by-products after $1 \mathrm{~h}$ of pretreatment; the compounds 5,7 , 8, 9 and 10 given in the Table 2 were detected. These compounds constituted a part of the carbon source available for microorganisms during the biological treatment. After $504 \mathrm{~h}$ of biological treatment of $1 \mathrm{~h}$ electrolysis by-products, a detection of these compounds was carried out by LC-MS/MS in order to determine the behavior of the microorganisms with respect to these by-products. The results showed that the compounds 9 and 10 disappeared (data not shown), showing their assimilation or biotransformation by the microorganisms while the other by-products were still detectable, namely compounds 5, 7 and 8 . However, the peak area corresponding to the compound 8 decreased (data not shown) demonstrating the ability of the microorganisms to biodegrade or biotransform at least partially this compound. Contrarily, compounds 5 and 7 were neither biodegraded nor biotransfomed; this may suggest that these compounds can be considered refractory and belongs to "Hard COD". The behavior of the microorganisms with respect to the compounds detected can be explained by the influence of the substituted groups on the imidazole ring. In fact, the compounds' biodegradation depends 
on the interactions between the microbial enzymes and the substrate. The substituents on the aromatic ring significantly influence the probability of enzymatic attack on the substrate [45]. Then it can be supposed that the assimilation of compounds 9 and 10 can be due to the presence of hydroxyl groups as a substituent on their imidazole ring, since their presence improves the biodegradability of organic compounds [46,47]. The lower degradation of compound 8 can be attributed to the presence of a steric hindrance between the alcohol group $\mathrm{OH}$ and the acid group $\mathrm{COOH}$. Several studies have described that the large volume and the steric effect of the substituents have a negative influence on the biodegradability $[45,48]$. However, the refractory character of the compounds 5 and 7 can be related to the presence of methyl group as substituent, since the presence of such group increases the persistence of the compounds [4648].

\section{Conclusion}

A biological treatment of metronidazole was carried out with activated sludge showing no mineralization of MTZ; whereas $22 \%$ of the MTZ was bio-transformed to 2-methyl-5nitroimidazole-1-acetic acid (MAA), a by-product that has a phytotoxicity on seed garden cress higher than MTZ. This result showed the relevance of an electrochemical pre-treatment. The degradation of MTZ by electro-Fenton was carried out leading to an increase in biodegradability. From $1 \mathrm{~h}$ of EF electrolysis, the by-products formed can be considered as partially biodegradable $\left(\mathrm{BOD}_{5} / \mathrm{DCO}=0.46\right)$; which was therefore considered as the optimum pretreatment time. After having verified the absence of biosorption of the electrolysis byproducts on the wall of the microorganisms present in the activated sludge, a biological treatment of the by-products electrolyzed for $1 \mathrm{~h}$ was then realized. Identification of the electrolysis by-products of MTZ during electro-Fenton and the biological treatment were carried out. A possible mechanism of MTZ degradation was then proposed. From the identification of the residual by-products after biological treatment, some explanations concerning the influence of their chemical structure on biodegradation were suggested. The mineralization yield after $504 \mathrm{~h}$ of biological treatment with activated sludge of an electrolyzed solution was $84.6 \%$, namely $87.4 \%$ of mineralization if both the pretreatment and the biological process were considered. These results show the efficiency of coupling an electroFenton process with a biological treatment with activated sludge for MTZ mineralization. 


\section{References}

[1] M. Klavarioti, D. Mantzavinos, D. Kassinos, Removal of residual pharmaceuticals from aqueous systems by advanced oxidation processes, Environ. Int. 35 (2009) 402-417.

[2] H.A. Duong, N.H. Pham, H.T. Nguyen, T.T. Hoang, H.V. Pham, V.C. Pham, M. Berg, W. Giger, A.C. Alder, Occurrence, fate and antibiotic resistance of fluoroquinolone antibacterials in hospital wastewaters in Hanoi, Vietnam, Chemosphere. 72 (2008) 968973.

[3] B. Halling-Sørensen, Inhibition of aerobic growth and nitrification of bacteria in sewage sludge by antibacterial agents, Arch. Environ. Contam. Toxicol. 40 (2001) 451-460.

[4] K. Kümmerer, The presence of pharmaceuticals in the environment due to human usepresent knowledge and future challenges, J. Environ. Manage. 90 (2009) 2354-2366.

[5] D. Bretagne, La pollution de l'eau d'origine industrielle - Panorama 2007/2008, (2016). http://www.statistiques.developpement-durable.gouv.fr/lessentiel/ar/333/1200/rejetsleau-lindustrie.html.

[6] E. Çalışkan, S. Göktürk, Adsorption characteristics of sulfamethoxazole and metronidazole on activated carbon, Sep. Sci. Technol. 45 (2010) 244-255.

[7] J. Rivera-Utrilla, G. Prados-Joya, M. Sánchez-Polo, M.A. Ferro-García, I. BautistaToledo, Removal of nitroimidazole antibiotics from aqueous solution by adsorption/bioadsorption on activated carbon, J. Hazard. Mater. 170 (2009) 298-305.

[8] J.D. Méndez-Díaz, G. Prados-Joya, J. Rivera-Utrilla, R. Leyva-Ramos, M. Sánchez-Polo, M.A. Ferro-García, N.A. Medellín-Castillo, Kinetic study of the adsorption of nitroimidazole antibiotics on activated carbons in aqueous phase, J. Colloid Interface Sci. 345 (2010) 481-490.

[9] M. Vertzoni, A. Carlsson, B. Abrahamsson, K. Goumas, C. Reppas, Degradation kinetics of metronidazole and olsalazine by bacteria in ascending colon and in feces of healthy adults, Int. J. Pharm. 413 (2011) 81-86. doi:10.1016/j.ijpharm.2011.04.028.

[10] F. Ingerslev, B. Halling-Sørensen, Biodegradability of Metronidazole, Olaquindox, and Tylosin and Formation of Tylosin Degradation Products in Aerobic Soil-Manure Slurries, Ecotoxicol. Environ. Saf. 48 (2001) 311-320. doi:10.1006/eesa.2000.2026.

[11] I. Oller, S. Malato, Ja. Sánchez-Pérez, Combination of advanced oxidation processes and biological treatments for wastewater decontamination — a review, Sci. Total Environ. 409 (2011) 4141-4166.

[12] O. Ganzenko, D. Huguenot, E.D. Van Hullebusch, G. Esposito, M.A. Oturan, Electrochemical advanced oxidation and biological processes for wastewater treatment: a review of the combined approaches, Environ. Sci. Pollut. Res. 21 (2014) 8493-8524.

[13] F. Ferrag-Siagh, F. Fourcade, I. Soutrel, H. Aït-Amar, H. Djelal, A. Amrane, Tetracycline degradation and mineralization by the coupling of an electro-Fenton pretreatment and a biological process, J. Chem. Technol. Biotechnol. 88 (2013) 1380-1386.

[14] D. Mansour, F. Fourcade, S. Huguet, I. Soutrel, N. Bellakhal, M. Dachraoui, D. Hauchard, A. Amrane, Improvement of the activated sludge treatment by its combination with electro Fenton for the mineralization of sulfamethazine, Int. Biodeterior. Biodegrad. 88 (2014) 29-36.

[15] K. Jüttner, U. Galla, H. Schmieder, Electrochemical approaches to environmental problems in the process industry, Electrochimica Acta. 45 (2000) 2575-2594.

[16] H. Olvera-Vargas, C. Trellu, N. Oturan, M.A. Oturan, Bio-electro-Fenton: A New Combined Process - Principles and Applications, in: SpringerLink, Springer, Berlin, Heidelberg, 2017: pp. 1-28. doi:10.1007/698_2017_53. 
[17] C. Annabi, F. Fourcade, I. Soutrel, F. Geneste, D. Floner, N. Bellakhal, A. Amrane, Degradation of enoxacin antibiotic by the electro-Fenton process: Optimization, biodegradability improvement and degradation mechanism, J. Environ. Manage. 165 (2016) 96-105.

[18] E. Brillas, I. Sirés, M.A. Oturan, Electro-Fenton process and related electrochemical technologies based on Fenton's reaction chemistry, Chem. Rev. 109 (2009) 6570-6631.

[19] I. Saidi, I. Soutrel, D. Floner, F. Fourcade, N. Bellakhal, A. Amrane, F. Geneste, Indirect electroreduction as pretreatment to enhance biodegradability of metronidazole, J. Hazard. Mater. 278 (2014) 172-179. doi:10.1016/j.jhazmat.2014.06.003.

[20] A. Bendesky, D. Menéndez, P. Ostrosky-Wegman, Is metronidazole carcinogenic?, Mutat. Res. 511 (2002) 133-144.

[21] P.F. Lanzky, B. Halting-Sørensen, The toxic effect of the antibiotic metronidazole on aquatic organisms, Chemosphere. 35 (1997) 2553-2561.

[22] J.L. Ré, M.P. De Méo, M. Laget, H. Guiraud, M. Castegnaro, P. Vanelle, G. Duménil, Evaluation of the genotoxic activity of metronidazole and dimetridazole in human lymphocytes by the comet assay, Mutat. Res. Mol. Mech. Mutagen. 375 (1997) 147-155.

[23] P. Liu, Q. Wang, C. Zheng, C. He, Sorption of Sulfadiazine, Norfloxacin, Metronidazole, and Tetracycline by Granular Activated Carbon: Kinetics, Mechanisms, and Isotherms, Water. Air. Soil Pollut. 228 (2017) 129.

[24] A. Khataee, M. Kıranşan, S. Karaca, M. Sheydaei, Photocatalytic ozonation of metronidazole by synthesized zinc oxide nanoparticles immobilized on montmorillonite, J. Taiwan Inst. Chem. Eng. 74 (2017) 196-204.

[25] H.B. Ammar, Sono-Fenton process for metronidazole degradation in aqueous solution: Effect of acoustic cavitation and peroxydisulfate anion, Ultrason. Sonochem. 33 (2016) 164-169.

[26] F.N. Chianeh, J.B. Parsa, Electrochemical degradation of metronidazole from aqueous solutions using stainless steel anode coated with $\mathrm{SnO} 2$ nanoparticles: experimental design, J. Taiwan Inst. Chem. Eng. 59 (2016) 424-432.

[27] H. Shemer, Y.K. Kunukcu, K.G. Linden, Degradation of the pharmaceutical metronidazole via UV, Fenton and photo-Fenton processes, Chemosphere. 63 (2006) 269-276.

[28] T. Pérez, S. Garcia-Segura, A. El-Ghenymy, J.L. Nava, E. Brillas, Solar photoelectroFenton degradation of the antibiotic metronidazole using a flow plant with a Pt/airdiffusion cell and a CPC photoreactor, Electrochimica Acta. 165 (2015) 173-181. doi:10.1016/j.electacta.2015.02.243.

[29] A. Aboudalle, F. Fourcade, A.A. Assadi, L. Domergue, H. Djelal, T. Lendormi, S. Taha, A. Amrane, Reactive oxygen and iron species monitoring to investigate the electro-Fenton performances. Impact of the electrochemical process on the biodegradability of metronidazole and its by-products, Chemosphere. 199 (2018) 486-494. doi:10.1016/j.chemosphere.2018.02.075.

[30] J.-M. Fontmorin, F. Fourcade, F. Geneste, D. Floner, S. Huguet, A. Amrane, Combined process for 2, 4-Dichlorophenoxyacetic acid treatment-Coupling of an electrochemical system with a biological treatment, Biochem. Eng. J. 70 (2013) 17-22.

[31] J. Rodier, C. Bazin, J.P. Broutin, L'analyse de l'eau: eaux naturelles, eaux résiduaires et de mer: chimie, physico-chimie, microbiologie, biologie, interprétation des résultats, Dunod, 1996.

[32] J. Yang, X. Wang, M. Zhu, H. Liu, J. Ma, Investigation of PAA/PVDF-NZVI hybrids for metronidazole removal: synthesis, characterization, and reactivity characteristics, J. Hazard. Mater. 264 (2014) 269-277. 
[33] W. Cheng, M. Yang, Y. Xie, B. Liang, Z. Fang, E.P. Tsang, Enhancement of mineralization of metronidazole by the electro-Fenton process with a $\mathrm{Ce} / \mathrm{SnO} 2-\mathrm{Sb}$ coated titanium anode, Chem. Eng. J. 220 (2013) 214-220.

[34] H.B. Ammar, M.B. Brahim, R. Abdelhédi, Y. Samet, Green electrochemical process for metronidazole degradation at BDD anode in aqueous solutions via direct and indirect oxidation, Sep. Purif. Technol. 157 (2016) 9-16. doi:10.1016/j.seppur.2015.11.027.

[35] H.B. Ammar, M.B. Brahim, R. Abdelhédi, Y. Samet, Enhanced degradation of metronidazole by sunlight via photo-Fenton process under gradual addition of hydrogen peroxide, J. Mol. Catal. Chem. 420 (2016) 222-227. doi:10.1016/j.molcata.2016.04.029.

[36] J. Chen, X. Qiu, Z. Fang, M. Yang, T. Pokeung, F. Gu, W. Cheng, B. Lan, Removal mechanism of antibiotic metronidazole from aquatic solutions by using nanoscale zerovalent iron particles, Chem. Eng. J. 181-182 (2012) 113-119. doi:10.1016/j.cej.2011.11.037.

[37] Z. Fang, X. Qiu, J. Chen, X. Qiu, Degradation of metronidazole by nanoscale zero-valent metal prepared from steel pickling waste liquor, Appl. Catal. B Environ. 100 (2010) 221228. doi:10.1016/j.apcatb.2010.07.035.

[38] N.A. Salles, F. Fourcade, F. Geneste, D. Floner, A. Amrane, Relevance of an electrochemical process prior to a biological treatment for the removal of an organophosphorous pesticide, phosmet, J. Hazard. Mater. 181 (2010) 617-623. doi:10.1016/j.jhazmat.2010.05.057.

[39] J.P. Bell, M. Tsezos, Removal of hazardous organic pollutants by biomass adsorption, J. Water Pollut. Control Fed. (1987) 191-198.

[40] F. Ferrag-Siagh, F. Fourcade, I. Soutrel, H. Aït-Amar, H. Djelal, A. Amrane, ElectroFenton pretreatment for the improvement of tylosin biodegradability, Environ. Sci. Pollut. Res. 21 (2014) 8534-8542. doi:10.1007/s11356-014-2771-5.

[41] M. Zaghdoudi, F. Fourcade, I. Soutrel, D. Floner, A. Amrane, H. Maghraoui-Meherzi, F. Geneste, Direct and indirect electrochemical reduction prior to a biological treatment for dimetridazole removal, J. Hazard. Mater. 335 (2017) 10-17.

[42] Z. Aksu, Application of biosorption for the removal of organic pollutants: a review, Process Biochem. 40 (2005) 997-1026. doi:10.1016/j.procbio.2004.04.008.

[43] L. Dobiáš, M. Černá, P. Rössner, R. Šrám, Genotoxicity and carcinogenicity of metronidazole, Mutat. Res. Genet. Toxicol. 317 (1994) 177-194. doi:10.1016/01651110(94)90001-9.

[44] S.L. Pendland, S.C. Piscitelli, P.C. Schreckenberger, L.H. Danziger, In vitro activities of metronidazole and its hydroxy metabolite against Bacteroides spp., Antimicrob. Agents Chemother. 38 (1994) 2106-2110.

[45] P. Degner, M. Nendza, W. Klein, Predictive QSAR models for estimating biodegradation of aromatic compounds, Sci. Total Environ. 109 (1991) 253-259. doi:10.1016/00489697(91)90182-E.

[46] O. Muter, I. Plerkons, T. Selga, A. Berzins, D. Gudra, I. Radovica-Spalvina, D. Fridmanis, V. Bartkevics, Removal of pharmaceuticals from municipal wastewaters at laboratory scale by treatment with activated sludge and biostimulation, Sci. Total Environ. 584-585 (2017) 402-413. doi:10.1016/j.scitotenv.2017.01.023.

[47] C. Bertelkamp, A.R.D. Verliefde, J. Reynisson, N. Singhal, A.J. Cabo, M. De Jonge, J.P. van der Hoek, A predictive multi-linear regression model for organic micropollutants, based on a laboratory-scale column study simulating the river bank filtration process, $\mathrm{J}$. Hazard. Mater. 304 (2016) 502-511.

[48] M. Alexander, Biodegradation and bioremediation, Gulf Professional Publishing, 1999. https://books.google.fr/books?hl=fr\&lr=\&id=cugVY4T9wW4C\&oi=fnd\&pg=PR13\&dq 
$=$ Biodegradation+and+Bioremediation\&ots $=1$ NUDJq_JwC\&sig=en5QPMqQ5jkfXIBU H-SA0mSxetA (accessed April 18, 2017).

\section{Figures Captions}

Fig. 1: Time-course of MTZ concentration $(\boldsymbol{\Delta})$ and TOC $(\diamond)$ during MTZ degradation by EF. Experimental conditions: $\mathrm{C}_{0} 100 \mathrm{mg} . \mathrm{L}^{-1}, 0.07 \mathrm{~mA} \cdot \mathrm{cm}^{-2},[\mathrm{Fe}(\mathrm{II})]=0.1 \mathrm{mmol} . \mathrm{L}^{-1}, \mathrm{pH}=3$, $\left[\mathrm{Na}_{2} \mathrm{SO}_{4}\right]=0.05 \mathrm{~mol} . \mathrm{L}^{-1}$.

Fig. 2: Pathway proposed for the mineralization of MTZ by the electro-Fenton process.

Fig. 3: Time-course of the concentration of inorganic species during MTZ degradation by EF. Experimental conditions: $\mathrm{C}_{0}=100 \mathrm{mg} . \mathrm{L}^{-1}, 0.07 \mathrm{~mA} . \mathrm{cm}^{-2},[\mathrm{Fe}(\mathrm{II})]=0.1 \mathrm{mmol} . \mathrm{L}^{-1}, \mathrm{pH}=3$, $\left[\mathrm{Na}_{2} \mathrm{SO}_{4}\right]=0.05 \mathrm{~mol} . \mathrm{L}^{-1}$.

Fig. 4: Evolution of the $\mathrm{BOD}_{5}$ on $\mathrm{COD}$ ratio during electrolysis. Experimental conditions: $\mathrm{C}_{0}$ $=100 \mathrm{mg} \cdot \mathrm{L}^{-1}, 0.07 \mathrm{~mA} \cdot \mathrm{cm}^{-2},[\mathrm{Fe}(\mathrm{II})]=0.1 \mathrm{mmol} \cdot \mathrm{L}^{-1}, \mathrm{pH}=3,\left[\mathrm{Na}_{2} \mathrm{SO}_{4}\right]=0.05 \mathrm{~mol} \cdot \mathrm{L}^{-1}$.

Fig. 5: Time-courses of adsorption on living (L) and dead (D) cells sludge, at $25^{\circ} \mathrm{C}$, initial pH 7 of $100 \mathrm{mg} . \mathrm{L}^{-1}$ non-treated MTZ (P) and MTZ solutions electrolyzed for $1 \mathrm{~h}(\mathrm{E})$ at pH 3, 0.07 $\mathrm{mA} . \mathrm{cm}^{-2},\left[\mathrm{Na}_{2} \mathrm{SO}_{4}\right]=0.05 \mathrm{~mol} \cdot \mathrm{L}^{-1}$ and $\left[\mathrm{Fe}^{2+}\right]=0.1 \mathrm{mmol} \cdot \mathrm{L}^{-1}$.

Fig. 6: Time-courses of the MTZ concentrations $(\boldsymbol{\Delta})$ and TOC $(\bullet)$ values during activated sludge culture on non-pretreated MTZ solution. $\mathrm{C}_{0}=100 \mathrm{mg} . \mathrm{L}^{-1}$ [Activated sludge] $=0.5 \mathrm{~g} . \mathrm{L}^{-}$ $1,200 \mathrm{rpm}, 25^{\circ} \mathrm{C}, \mathrm{pH}=7$

Fig. 7: HPLC chromatogram for MTZ degradation and by-product formation during the direct biological treatment.

Fig. 8: The phytotoxicity of the main MTZ molecule and the MAA byproducts formed during direct biological treatment. 
Fig. 9: Time-courses of the TOC values during activated sludge culture on pretreated MTZ solutions for $1 \mathrm{~h}(\boldsymbol{\bullet})$ and $2 \mathrm{~h}(\boldsymbol{\Delta})$. [Activated sludge] $=0.5 \mathrm{~g} \cdot \mathrm{L}^{-1}, 200 \mathrm{rpm}, 25^{\circ} \mathrm{C}, \mathrm{pH}=7$ 


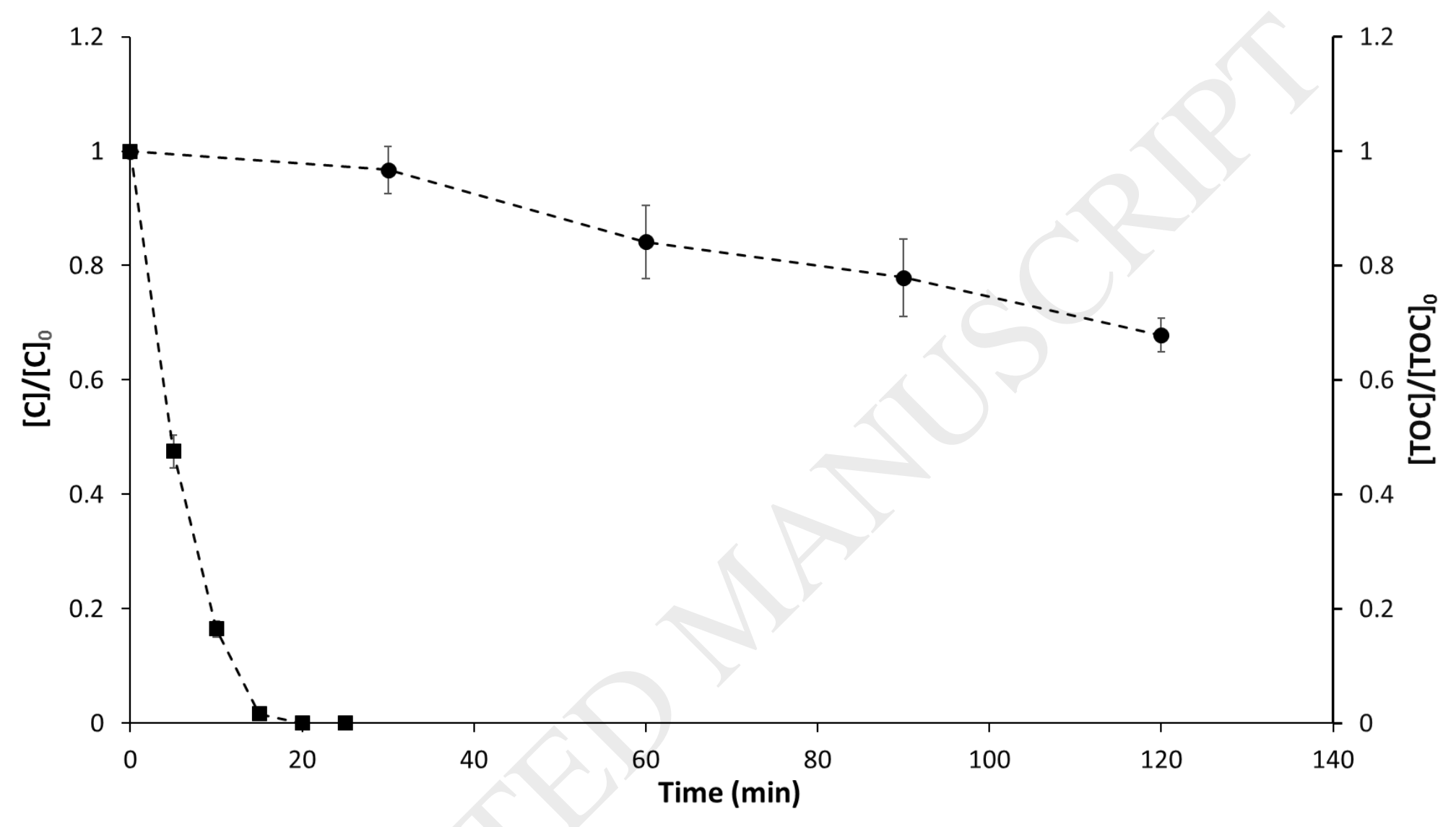




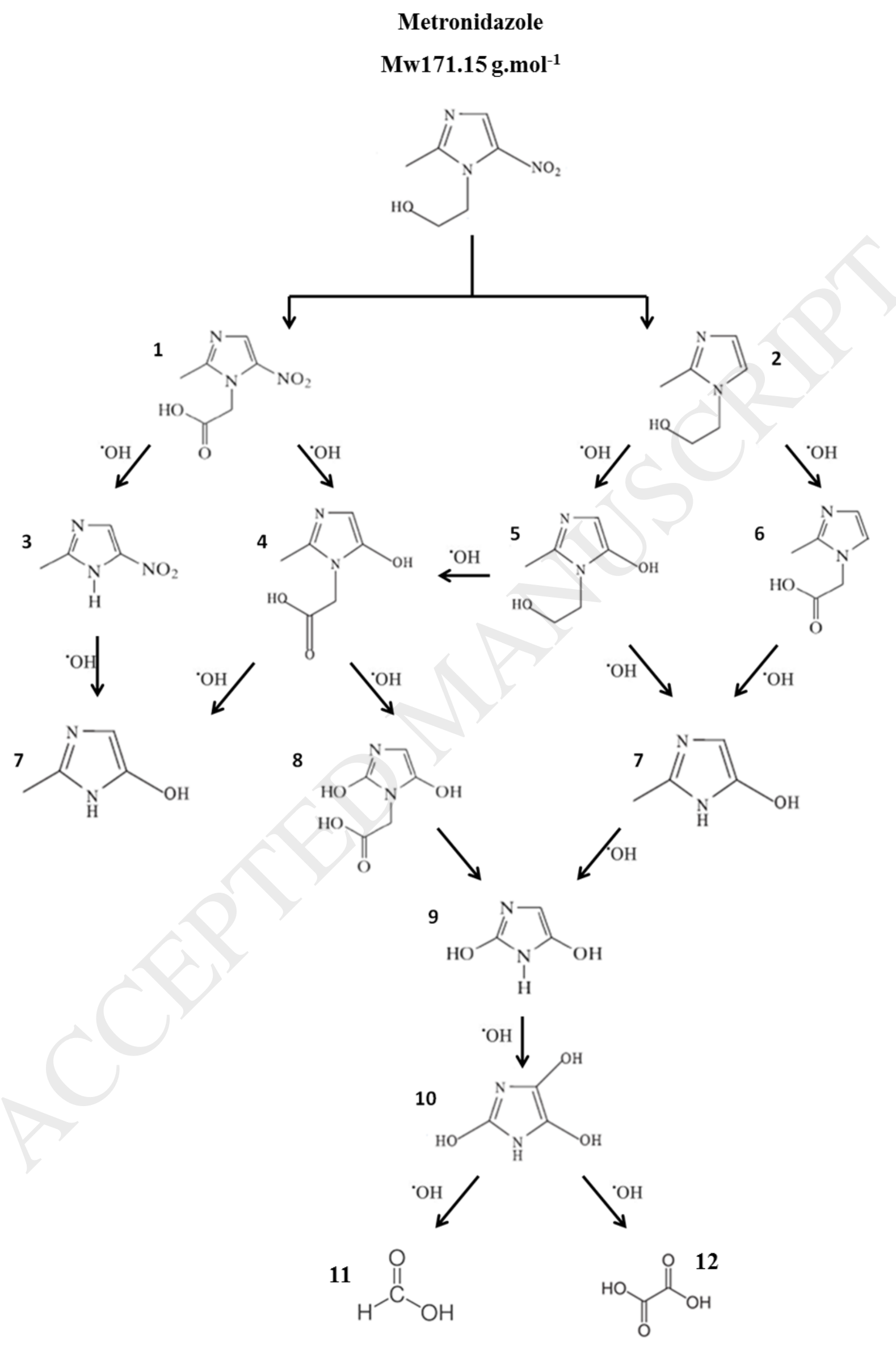




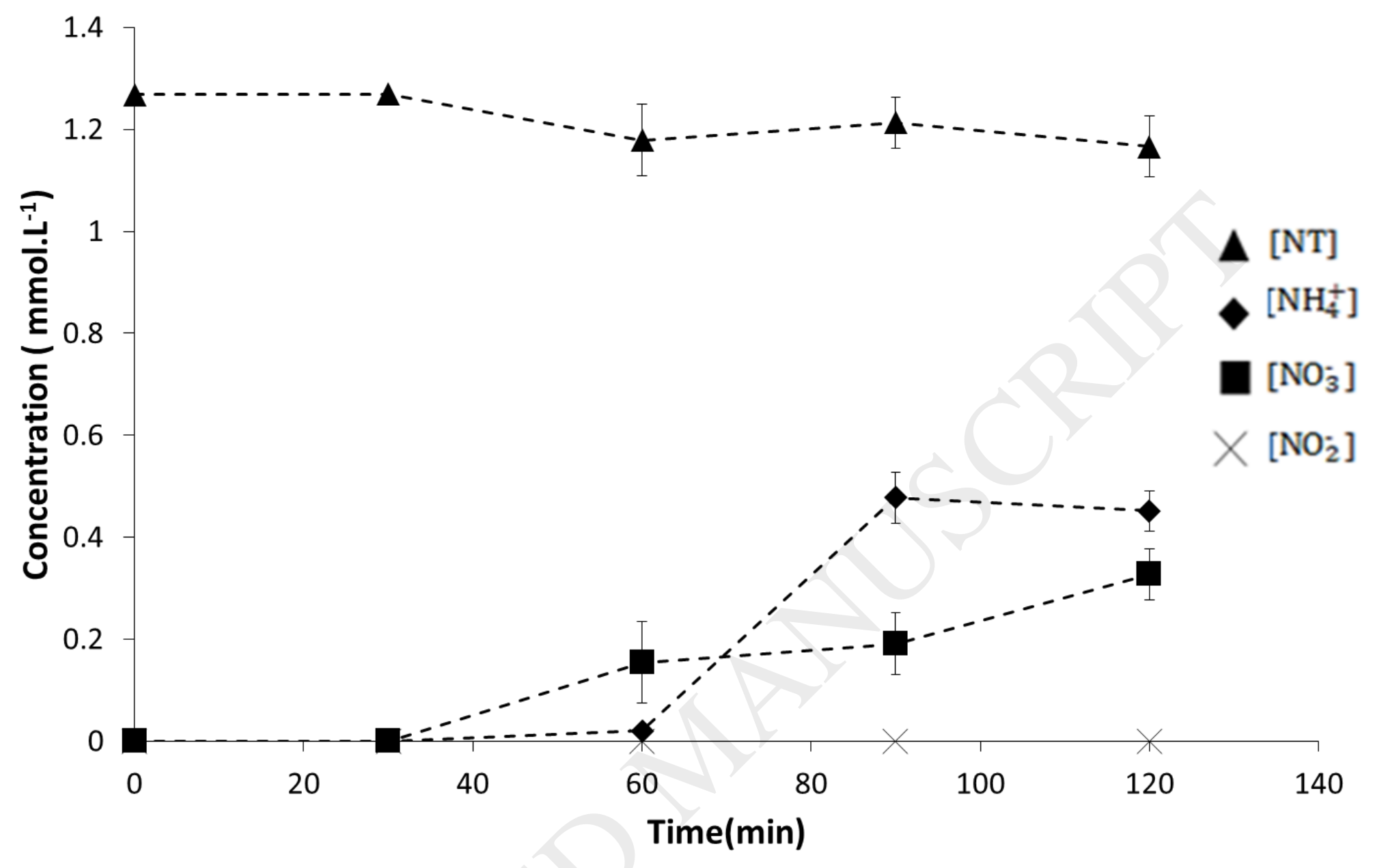




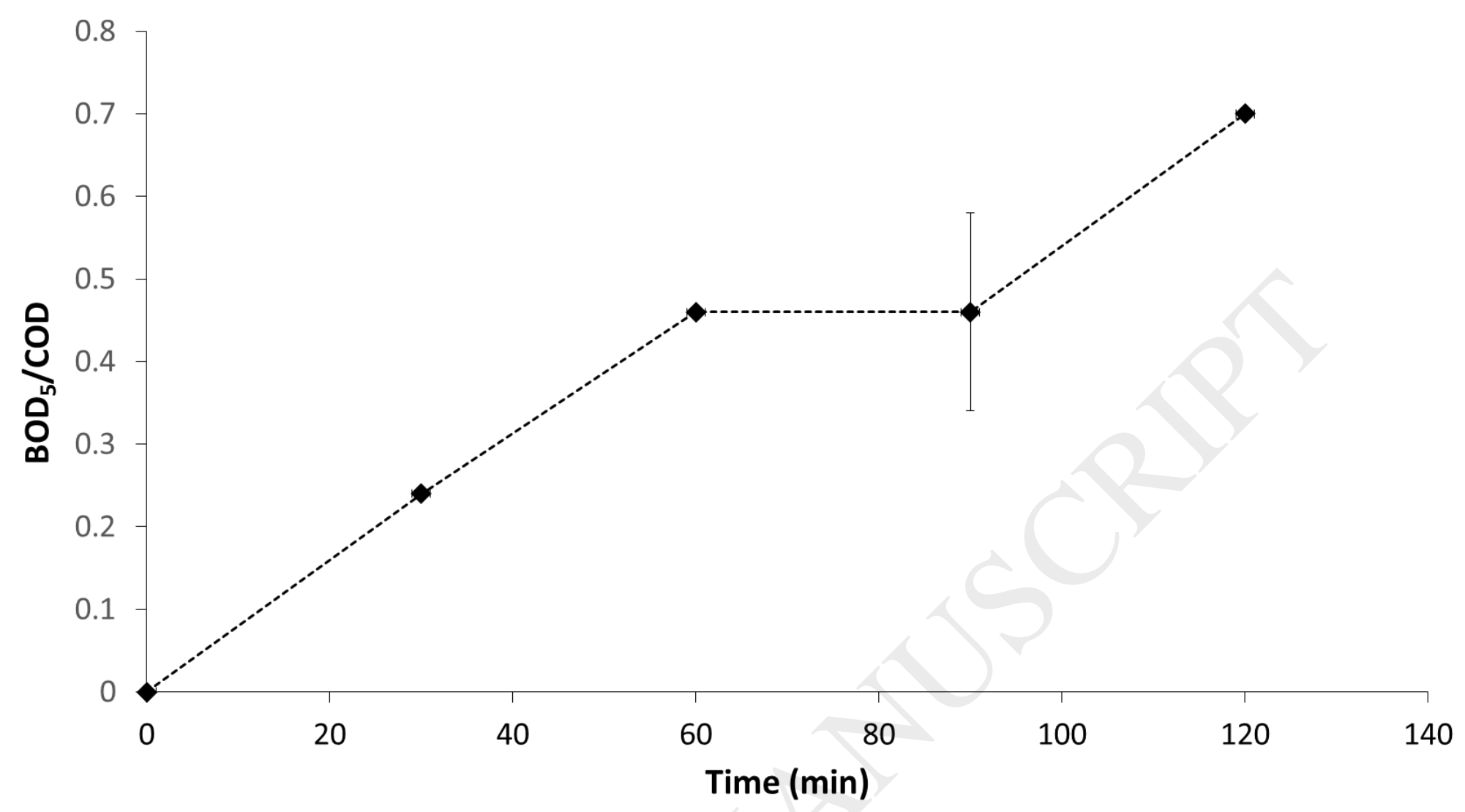




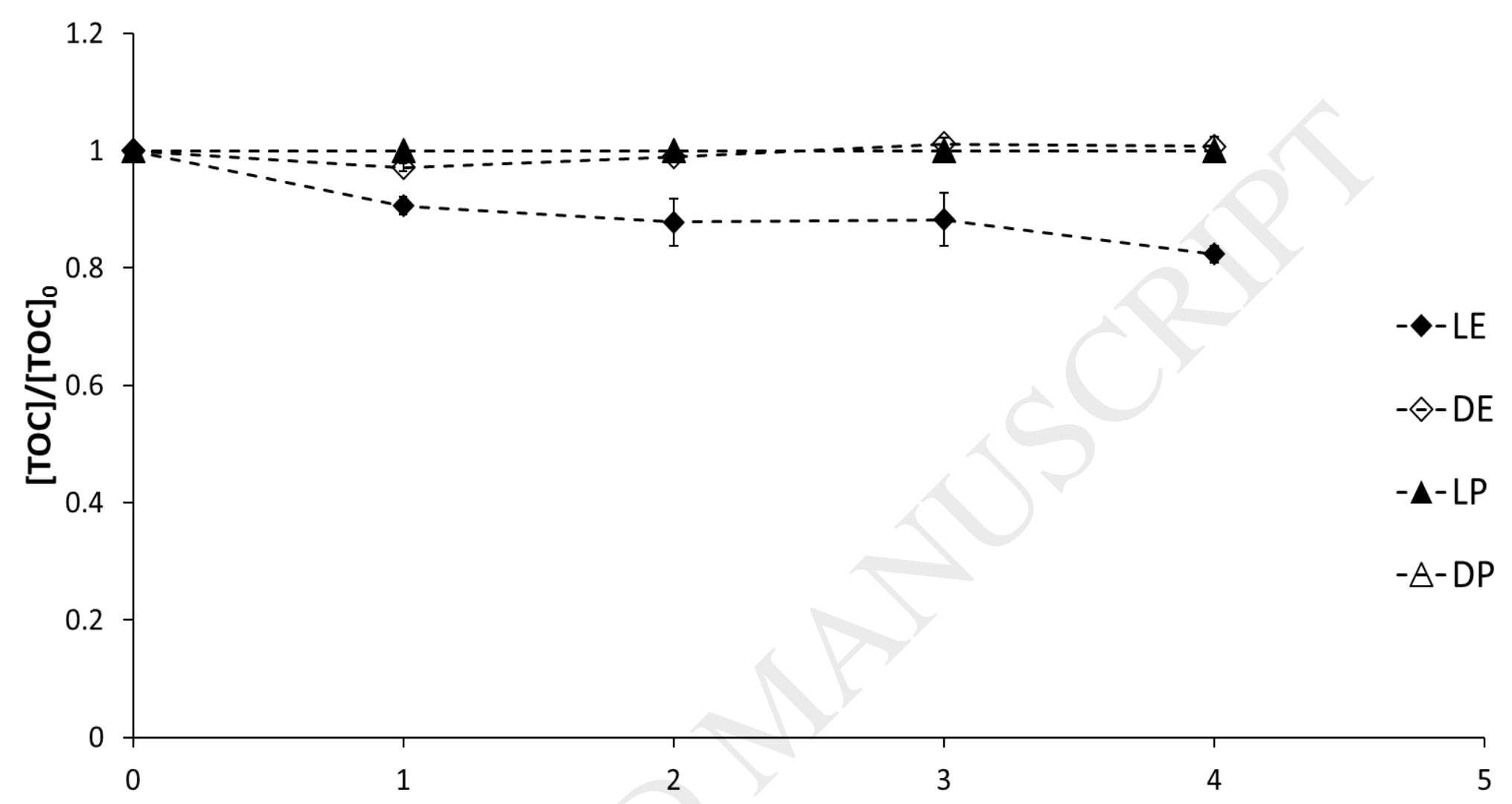

Time (h) 


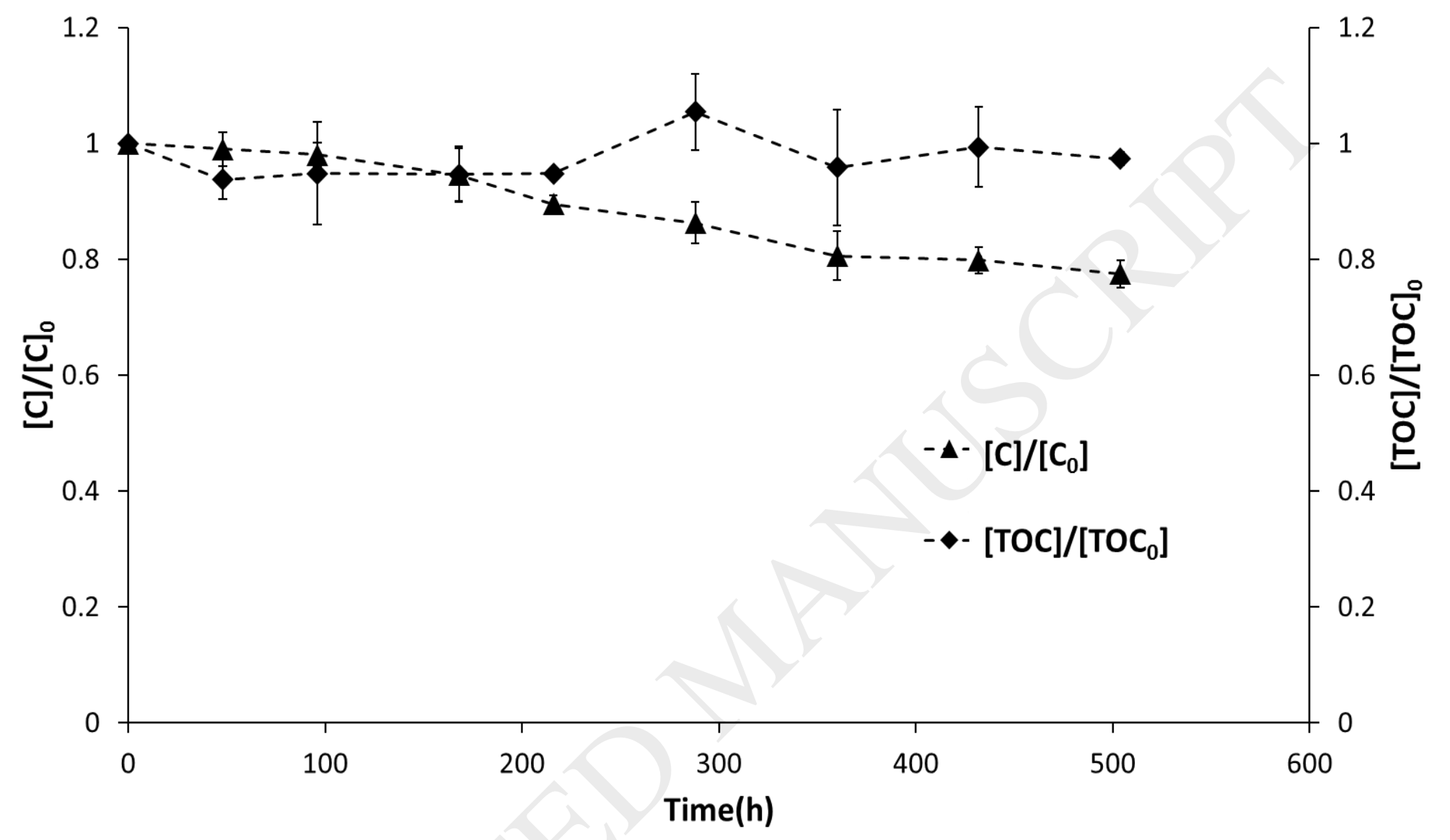




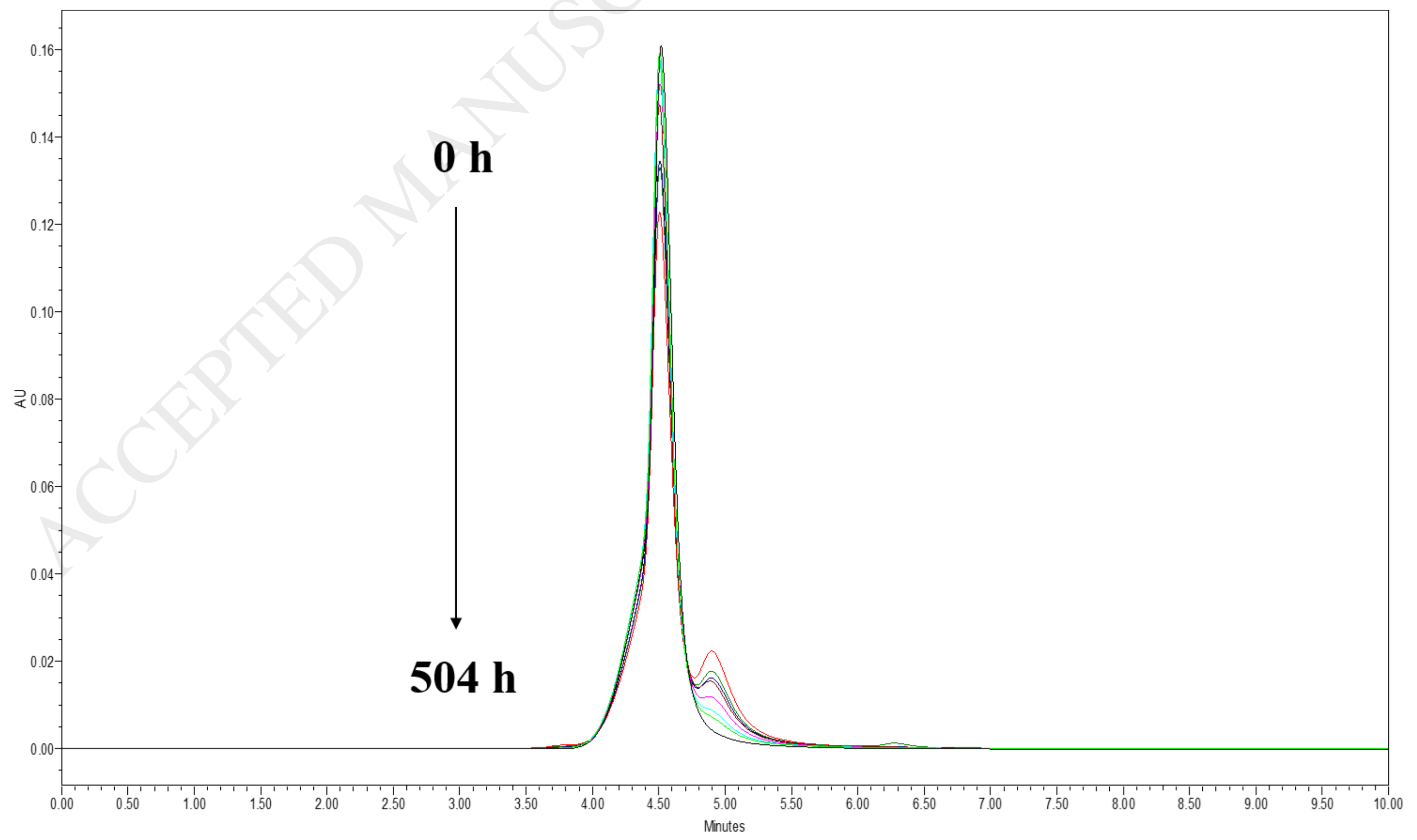




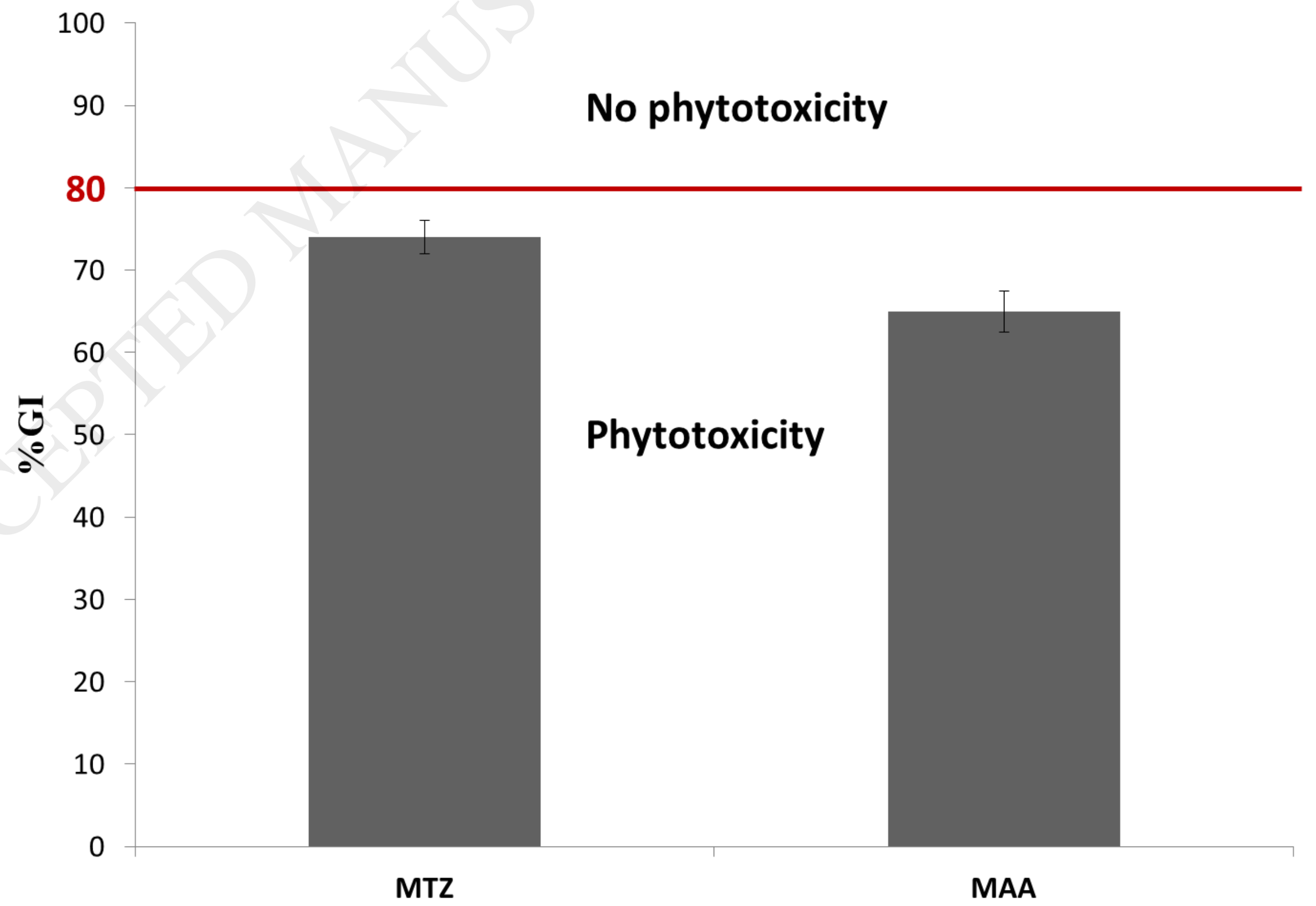




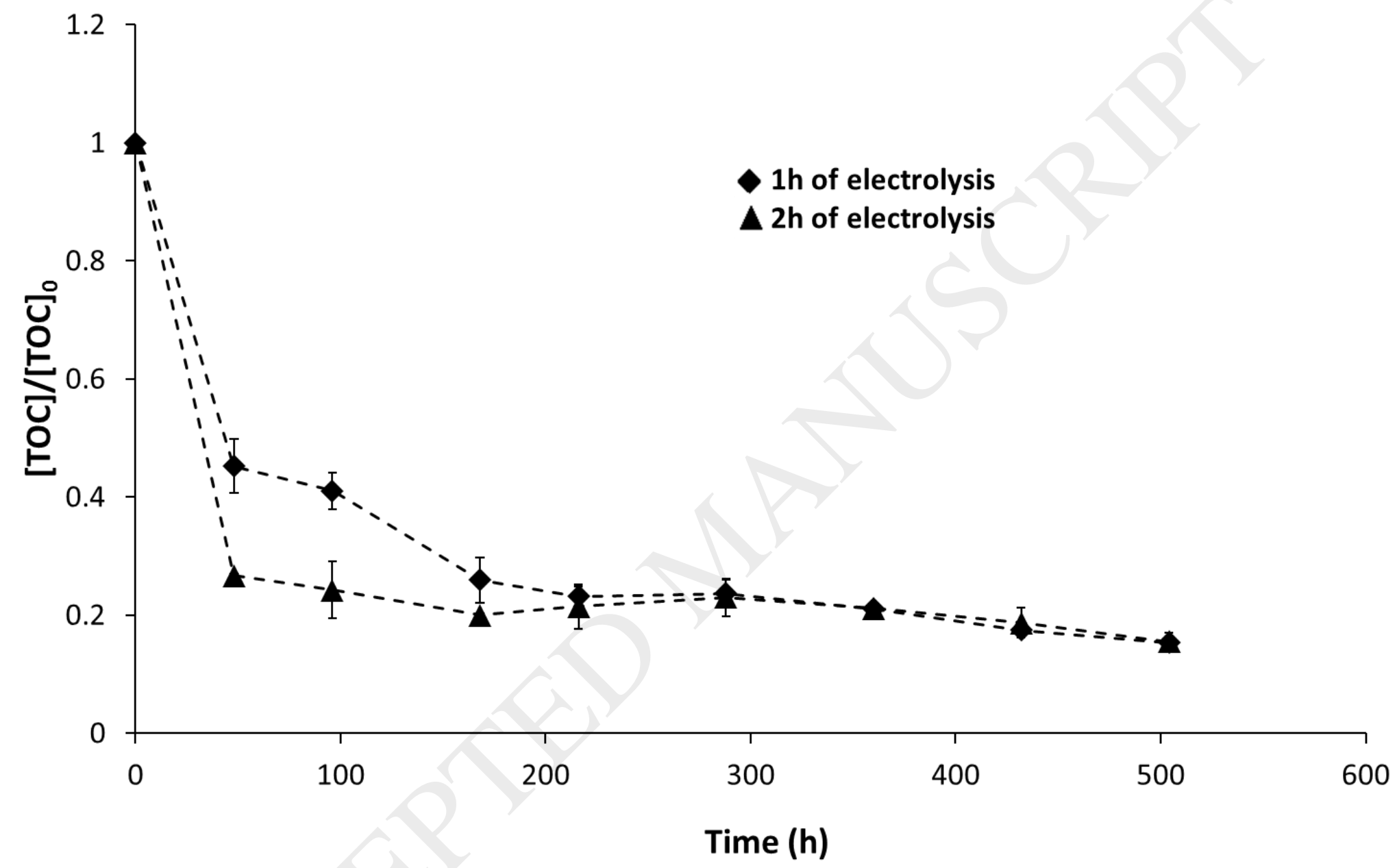




\section{Table Legends}

Table 1: The reagents used for the BOD test

\begin{tabular}{|c|c|c|}
\hline & Reagents & Concentration $\left(\mathrm{g} . \mathrm{L}^{-1}\right)$ \\
\hline \multirow{4}{*}{ Mineral basis } & $\mathrm{MgSO}_{4} .7 \mathrm{H}_{2} \mathrm{O}$ & 22.5 \\
\hline & $\mathrm{CaCl}_{2}$ & 27.5 \\
\hline & $\mathrm{FeCl}_{3}$ & 0.15 \\
\hline & $\mathrm{NH}_{4} \mathrm{Cl}$ & 2.0 \\
\hline \multirow{2}{*}{ Buffer solution } & $\mathrm{Na}_{2} \mathrm{HPO}_{4}$ & 6.80 \\
\hline & $\mathrm{KH}_{2} \mathrm{PO}_{4}$ & 2.80 \\
\hline Nitrification inhibitor & N-allylthiourea & 0.5 \\
\hline
\end{tabular}


Table 2: Intermediates products formed during the electrolytic degradation of metronidazole

\begin{tabular}{|c|c|c|c|}
\hline Compound & Name & Chemical structure & $\begin{array}{l}\text { Molar mass } \\
\left(\text { g.mol }{ }^{-1}\right)\end{array}$ \\
\hline 1 & $\begin{array}{c}\text { (2-methyl-5- } \\
\text { nitroimidazol-1-yl) acetic } \\
\text { acid }\end{array}$ & & 185 \\
\hline 2 & $\begin{array}{l}\text { 1-hydroxyethyl 2-methyl } \\
\text { imidazole }\end{array}$ & & 126 \\
\hline 3 & $\begin{array}{l}\text { 2-methyl 5- } \\
\text { nitroimidazole }\end{array}$ & & 127 \\
\hline 4 & $\begin{array}{l}\text { (5-hydroxy-2-methyl } \\
\text { imidazol-1-yl) acetic acid }\end{array}$ & & 156 \\
\hline 5 & $\begin{array}{l}\text { 1-hydroxyethyl 2-methyl } \\
\text { 5-hydroxyimidazol }\end{array}$ & & 142 \\
\hline 6 & $\begin{array}{l}\text { (2-methylimidazol-1-yl) } \\
\text { acetic acid }\end{array}$ & & 140 \\
\hline 7 & $\begin{array}{l}\text { 5-hydroxy 2-methyl- } \\
\text { imidazole }\end{array}$ & & 98 \\
\hline 8 & $\begin{array}{c}\text { 2,5-dihydroxyimidazol - } \\
\text { 1-yl- acetic acid }\end{array}$ & & 158 \\
\hline 9 & 2,5 dihydroxy imidazole & & 100 \\
\hline 10 & $\begin{array}{c}2,3,5- \\
\text { trihydroxyimidazole }\end{array}$ & & 116 \\
\hline 11 & Oxalic acid & & 90 \\
\hline 12 & Formic acid & & 46 \\
\hline
\end{tabular}

